\title{
Waste Recycle Management System based on Product Barcode
}

\author{
Abhijit Paradkar \\ ME Computer Engg student, \\ Dept. of Computer Engg. \\ K. J. Somaiya college of Engg., Vidyavihar, Mumbai, \\ India
}

\author{
Deepak Sharma \\ Associate Professor, \\ Dept. of Computer Engg. \\ K. J. Somaiya college of Engg., Vidyavihar, Mumbai, \\ India
}

\begin{abstract}
This paper proposed wastes recycle management system (including an e-waste) based on the barcode printed on the product. This system emphasize on building up the setup of secondary market to provide the recycling services for disposed of the waste in a formal ways that help to control the environmental issues. After analyzing the culture of Indian market, a market driven solution is proposed to reduce- to reuse and to recycle the product waste that enable the competition in the secondary market. As compare to earlier proposed ERP (Extended Responsibility of producer) system where the recycling responsibility has kept only on the shoulder of the producer, where as in proposed system the responsibility has been distributed among all the entities who plays an different ROLE's (like distributor-wholesaler (dealer)-retailer) in the product life cycle of that product. This system monitors the product waste until it has been finally recycled by the recycle firm and keeps the record of disposed waste. These records can be act as a references which provides the definite real data on "How much actual waste is generated and how much of it has been recycled in India" for the different research and government agencies.
\end{abstract}

\section{General Terms}

Wastes Recycle Management System.

\section{Keywords}

User Role $\left(\mathrm{U}_{\mathrm{ROLE}}\right)$, Deposit Criteria $\left(\mathrm{D}_{\mathrm{Cri}}\right)$, Deposit Release Criteria $\left(\mathrm{DR}_{\mathrm{Cri}}\right)$, Product Life cycle $\left(\mathrm{P}_{\mathrm{LC}}\right)$, Product Update Status $\left(\mathrm{P}_{\mathrm{US}}\right)$, Waste Update Status $\left(\mathrm{WP}_{\mathrm{US}}\right)$, Check Product Status $\left(\mathrm{P}_{\mathrm{S}}\right)$, Expire Product Status $\left(\mathrm{P}_{\mathrm{EX}}\right)$, Waste Product Life Cycle $\left(\mathrm{WP}_{\mathrm{LC}}\right)$, Waste Returned Status by the Customer $\left(\mathrm{WP}_{\mathrm{RS}}\right)$, Waste Reached the Recycle Firm ( $\left.\mathrm{WP}_{\mathrm{RRF}}\right)$, Waste Disposed Status by the Recycle Firm ( $\left.\mathrm{WP}_{\mathrm{DRF}}\right)$

\section{INTRODUCTION}

India which sees itself as a promising super power and an economic hub can achieve its goal only if the government able to utilized its budget plan on the development schemes which makes India as developed country in coming decade. All over the world under the "Tag name" of development-progressmodernization leads to a rapid growth in the industrialization through the invention of advance techniques and technologies. These techniques generate the byproduct as a waste in the form of solid, liquid or gases which can cause an environmental issue as well as affect the life cycle of all living organism. As in modern life style, everyone wants the rich comfortable life style through the electronics devices like refrigerator, television, mobile phones, washing machines etc or through mechanical devices like car, scooter etc or fast food sell in plastic rappers or plastic bottles etc. As everyone wants' almost the same which increase the demand in the market that leads to the market competition to develop the new advance techniques for manufacturing the product in less cost, to capture the market by keeping the prime focus only on earning the maximum profit without concerning about the quality and the waste generated by the product due to the concept of "use and throw" mechanism. The "use and Throw" mechanism leads to increased in concern over the used and obsolete products. The government spends the part of budget on recycling plan. As the government revenue is in the form of taxes. The waste materials generated from the product based on which the producer, distributor, retailer earns their profit, hence the responsibility of recycling in a formal way must be handed over to them through the system which in turn save the large amount of budget spend by the government over the waste recycled and can be utilized to fulfill the other primary needs as child education, women security etc.

Most of the dumping grounds are at their maximum limit due to the over burden of waste. This leads to a dispose of waste in the informal way that causes the various types of pollution which give the birth to the diseases like dengue, tuberculosis and other skin diseases. The government needs to spend a large amount of budget to provide various medical servicesfacility. The root causes behind the problem is the waste generated and the existing systems does not give the real view scenario of "how much waste has been recycled?", to solve these concerns a solution is needed to be searched. Many companies sell their products in the market of developed nations but to bypass the strict recycling rules and regulations of the developed countries, they used under developed countries like China, Pakistan, Afghanistan or India as a dump ground, through the secondary market. Since, the rules and regulation of under developed countries either are not too strict or not yet been implemented. At present china become the world largest dump ground for many e-waste products [1]. A study of MAIT reveals that, "As per the use of electronics every year, by end of year 2020 India is expected to generate about one and half lakh tone of wastage [2].

This paper proceeds as follows. First, in section 2 presents the study of several existing scenario, section 3 presents critical analysis, section 4 presents proposed model, section 5 presents the validation of proposed model and finally in Section 6 presents the conclusion.

\section{EXISTING APPROCHES}

\subsection{Green Computing}

This research paper[3] emphasize on the Green Computing approach which proposes an efficient use of the resources to reduce the power consumption along with it propose a plan to reduce the e-waste at each stage that is part of product life cycle of that product. A key term "Green" stands for the pollution free - healthful developing or recycling techniques for the environment and at the same time economically affordable. An Electronic Products Environmental Assessment Tool (EPEAT) used to test the products efficiency for the minimum power consumption and total expenditure on 
the maintenance of the product throughout their entire life cycle. It also provides the techniques that help to recycle the product hence reduced the e-waste.

Simple Techniques of "GREEN COMPUTING" :- a) The used of flat LCD monitors saves the $1 / 3$ the energy as compare to CRT monitors. b) The advance video card like ATI and nVidia card saves around $10 \%$ power consumption. c) To disable unused devices or ports that reduce energy consumption like Wi-Fi-Bluetooth-infrared, DVD drive, printer-scanner or sound card etc. Also lower down the brightness and enables the power saving features to saves the energy consumption. d) To check the computer power supply for the printed marking of " 80 Plus Certified", which indicates that the 80 percent efficiency of charging at the different ranges of loads. e) Use cloud computing to support the energy and resource efficiency.

\subsection{Role of the International Cooperation in Effective Waste Management}

This paper [4] reviews the driving forces behind the international trade in waste materials and characters the fragmentation in recycling industry. In the premise under that the concept of economic /social benefits of the environments can be exchanged among countries. This paper also offers the control steps to forms the international cooperation on the solution of effective e-waste management that increases ewaste treatment cooperation among the different countries.

The main objective of cooperative implementation endeavor on the ground of the international level is not only to accept but also to strictly implement the measure so as to reach their commitment and lower down the waste generations and manage wastes within their territory borders. But the real fact is that both developed and under developed counties fails to fulfill the restrictions put for the environmental standards due to lack of awareness of the environmental issues as compare to economical development. The strict rules of developed countries or other profit oriented reasons (cost difference) the recycling companies and traders are intend to export the environmental externalities (waste) to other nations. For an importing countries, they consider recycling as a business opportunity since it offer the secondary market employment through disassembling process the working condition part or components are extract and sell.

To obtain the positive trade difference, both importing and exporting countries give less attention to the environmental issues and more focus on waste recycle trade hence, the existing cooperative commitment plan about the environmental conservation are not work effectively. A Table given below shows the Impacts of Recycling Trades.

Table 1: Impacts of Recycling Trades

\begin{tabular}{|c|c|c|}
\hline Impact & Export Countries & Import Countries \\
\hline $\begin{array}{c}\text { Positive } \\
\text { Aspect }\end{array}$ & $\begin{array}{c}\text { Centralize collection, } \\
\text { Minimize all types of } \\
\text { pollution, Increase in } \\
\text { financial profits }\end{array}$ & $\begin{array}{c}\text { Resale products, } \\
\text { Employment, } \\
\text { Promote to invent } \\
\text { new technique for } \\
\text { recycling }\end{array}$ \\
\hline $\begin{array}{c}\text { Negativ } \\
\text { e Effect }\end{array}$ & $\begin{array}{l}\text { Environmental injustice } \\
\text { by export of hazardous. }\end{array}$ & $\begin{array}{c}\text { Human health and } \\
\text { environmental issues. }\end{array}$ \\
\hline
\end{tabular}

Negative Effect on both countries is as follows: Both the countries loss their revenue due to increase in illegal trade.

\subsection{E-Waste Management System, China}

This paper [5] discuss the ERP system stands for "Environmental Protection Responsibilities" proposed by Thomas Lindhqvist and define as follows: "EPR act as an environmental protection strategy and used to reduce the product's negative impact on the environment" and also proposed the EPR model, in which the responsibilities are put on to the producer shoulder [6]. The development growth of China's socially and economically, by capturing the various nations market with low cost (low standard, non - recyclable) china products which leads to serious environmental pollution problem. Due to the ignorance and less attention on implementation of waste management system leads to the recycling problems which reduced the international trade.

However, the production and recycle responsibility of an industry are different. The most important factor and the main responsibility define are purely based on the status, type of waste and recycle management system based on the characteristics specified by each industries [7].

\subsection{E-Waste Management and Regulatory System in the United States (U.S.)}

This paper [8] reviews the existing e-waste management recycling systems in U.S. and proposed the new technique for e-waste management systems. The idea behind the proposed system is based on the establishing competitive recycling market where user will select the profitable reuse and recycling services. The name given to the proposed system is an "e-Market for Returned Deposit". The customer pays the deposit to the retailer at the time of product purchase through electronic registration. The product trace at all the time using the Radio Frequency Identification Device (RFID) placed on the product. At the end of life cycle, customer put its product for recycled where the recycling firms compete for waste by offering the various degree of return on deposit. A firm selected by the customer receives the deposit and as per their offer customer get back its deposit. Now, the responsibility of that firm is to recycle the product.

\subsection{E-Waste Management - Indian Perspective}

This paper [9] presents existing e-waste scenario and recent legislations rules in India 2011 [10] (effect start from 1st May 2012) with its limitations. The e- waste [11] rule discuss the responsibility of Producer, Distributor, Retailer and Consumer to sale, purchase, recycles the electronic material and get authorization from the committee of pollution control board. This paper also reviews the sectors are not cover under the law like In-formal [12] recycling which causes the Health and environmental issues. It also discusses formal recycling [13] companies based on extended producer responsibility (ERP).

Under the regulatory act 2011, to control the E-Waste management the various companies [14] (like HP, Toshiba, Apple, Lexmark, Epson, Gateway, Sony, Whirlpool, IBM and Dell) initiate to provide the channel to collect their products for recycling in an environment friendly formal way, through authorized recyclers. Since, this regulation on the e-waste management leads to expand its authorized recycling capacity towards the green end of recycling solution [15] and strict punishment action must be taken on those who illegally import the e-waste in India [16].The Improper Disposal of Electronic Waste makes Environmental Impact [17] as well as the pollution problems which lead to the hazardous effects on human life [18]. The Central Pollution Control Board, India 
maintains the accountability of e-waste based on the annual returns filling by various stakeholders.

\section{CRITICAL ANALYSIS}

Reason for not making the Recycling Plan by Producers: a) First understand the strategy of manufacturing companies in different countries like in china. In china, the primary minimum requirement to manufacture the single outlet of the product like PCB-board, IC etc is to have a "die design" of that of product. Once the die gets ready the next step is to set all the instruments to its default value and write the program or code of instructions to automate the process to generate the large number of identical products. The cost of step 2 is veryvery high as compare to the total cost of secondary material used to form the product. As once the setup of step 2 successfully completed, it generates the large quantity of products in less amount of time without modification of the settings. Since, the major part of the cost is depends on the settings. Hence as the quantity number in the order increases to a large margin then also the total manufacturing / production cost will not affect in that proportionality. Since the quantity of product numbers and the total cost follows the relationship of the exponential curve graphs and not the equation of linear straight line. Hence to get instant profit, the manufactures sell the products without testing its standard and without warranty in very less amount as compare to the standard product. Some of such products are famous by the name "China Product". Such products (including the toys of kids) in the market normally create the e-waste, mechanical waste or plastic waste as in case of any damage these manufacturing company not offer the maintenance service which leads to obsolete product.

b) The large difference in the production, demands and distributions of electricity all over the India, the Indian people uses the CFL or LED bulbs to conserve the electricity. The central government not yet makes any marking system for LED bulb. The manufacturers of China are well aware of this fact and taking the benefit of it by capturing the Indian market with costly less reliable Light Emitting Diode (LED) bulbs. Since it is part of import products India needs to spend a lot of foreign exchanges currency onto the fulfillment of the large demand of customer but without ensuring and getting the good quality service guaranty, due to lack of marking system. In India, the uniqueness and purity of the products can be determine base on the certification mark like ISI, AG-MARK, FPO, WOOL-MARK, HALLMARK etc on the products. c) As many companies want to sell the products but don't want to invest the money on service centre setup consisting of the front and back end supporting staff. Hence, after selling the less quality products to the customer, these foreign companies can easily escaped from the country due to less or no investment in service centre.

\section{PROPOSED SYSTEM}

\subsection{System Architecture}

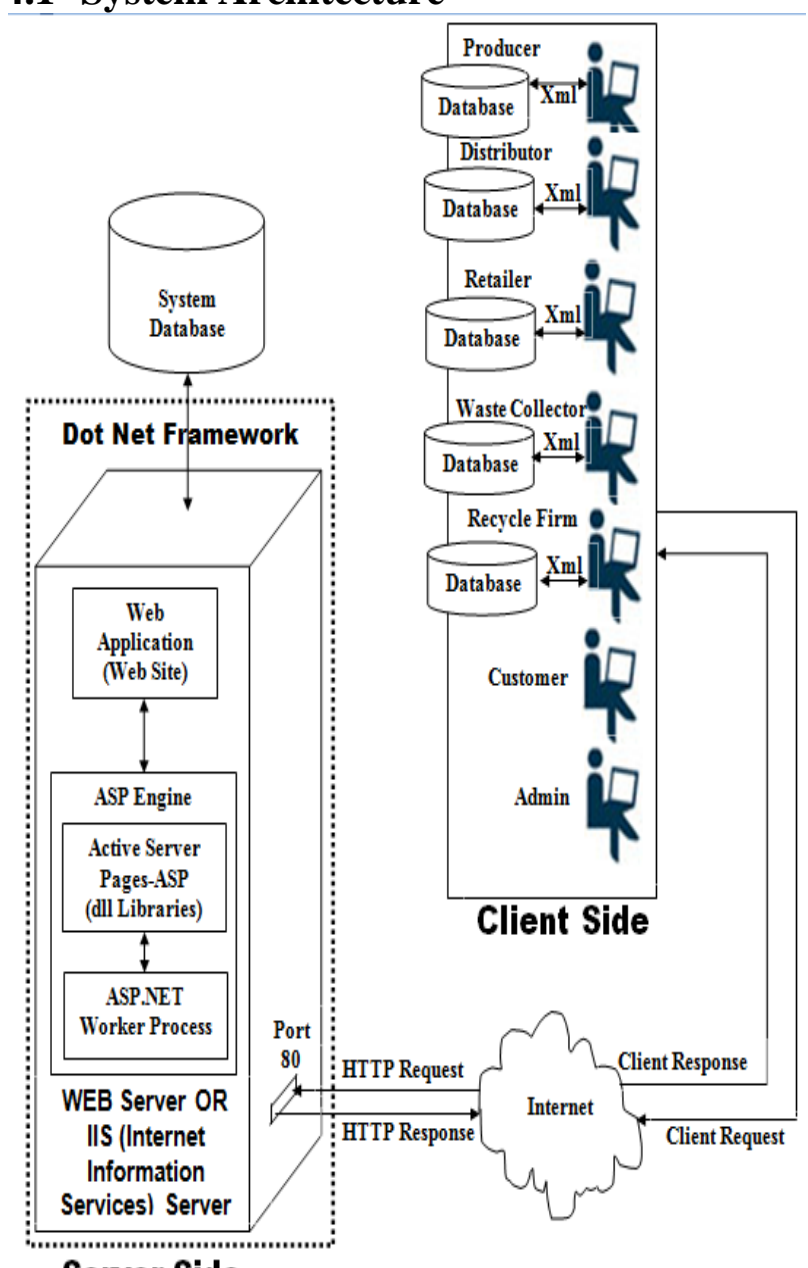

Server Side

Fig 4.1: System Architecture 
4.2 Input- Output Modules of the System

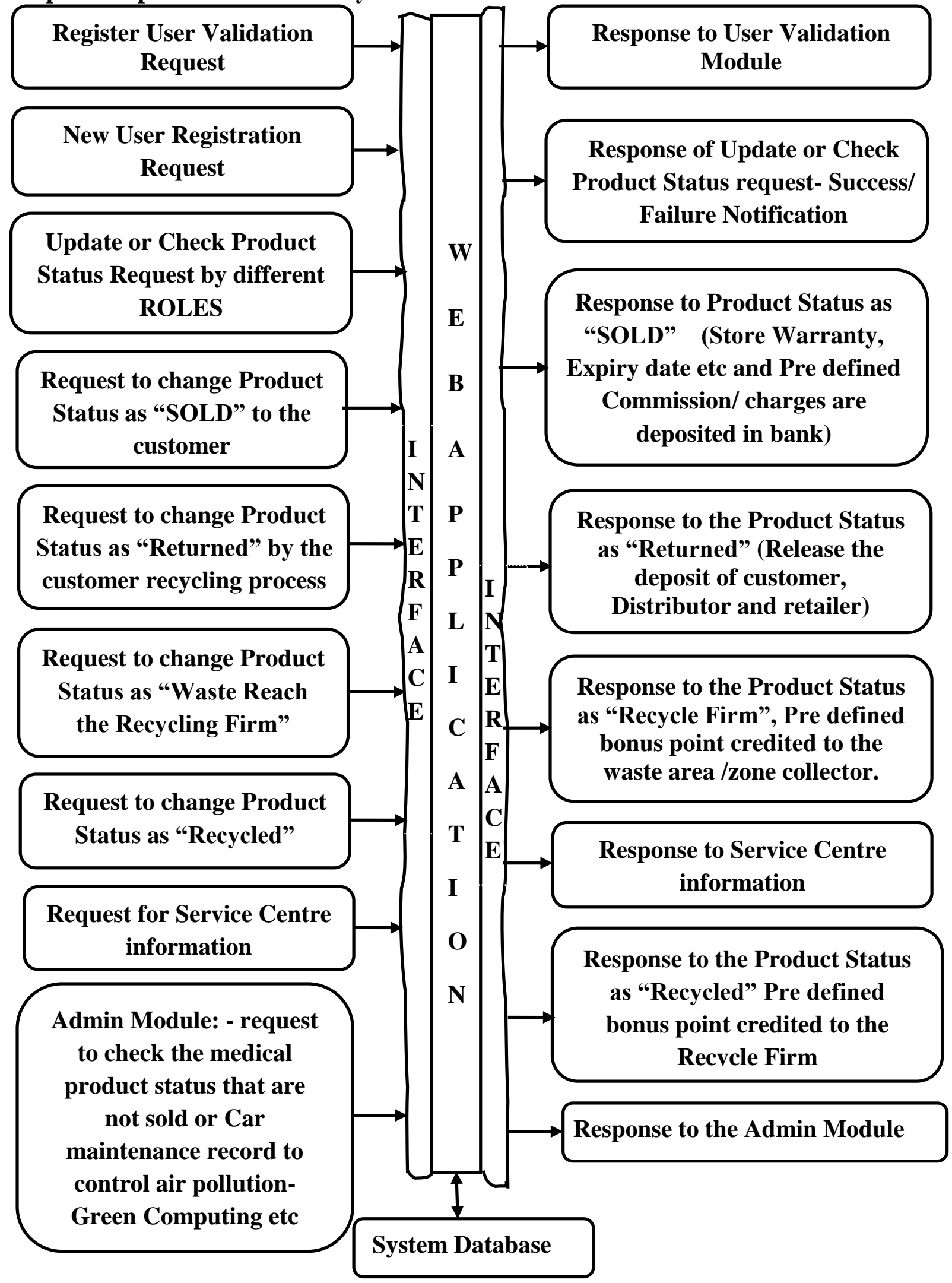

Fig 3.1: Input- Output Modules of the System 


\subsection{Explanation of Modules}

\subsubsection{Input Modules}

1. New User Registration Module: -To register the new user with the system. A PAN card number issued on the name of individual or on the name of company is mandatory.

2. Registered User Validation Module: -To access the functionality of the system user needs to enter the username and the password which is registered at the time of Registration process.

3. Request to update the Product Status as "SOLD" to the customer: - The customer pay an extra charges that has been included in mentioned MRP (Maximum Retail Prize) which is get deposited in bank. Also, a pre-defined part of commission of the distributor-wholesaler (dealer)retailer on the sales of each product, is deposited in bank and credited when the customer returned the product waste. Since, many malls and wholesaler directly sell the product to the customer with mega discounts, due to that customer may ignore to return the waste. Hence the recycle responsibility is also added on their shoulder, which enforced them to offer the mega discount if and only if the product waste has been returned by the customer. This provision increases the success ratio of the system.

4. Request to update the Product Status as "Returned": - At the end of product life cycle customer return back the product waste to the appropriate authority which initiate, the waste product life cycle (WPLC).

5. Request to update the Product Status as "REACHED RECYCLE FIRM" : - If the "Status of the product has "REACHED RECYCLE FIRM" the bonus point release to the area waste collector as well as the zone waste collector [Note: distributor allow to act as area/zone waste collector].

6. Request to update the Product Status as "RECYCLED or Disposed Waste": - If the "Status of the product has "RECYCLED" then the bonus point release to the recycle firm. [Note: - If waste material gets collected by the private waste collector then the part of deposit of retailer, distributor as per the rule are deducted and given to them.]

7. Ask for Service Centre information: -To return the waste product or waste product material, customer or other entities may ask for a recycle Service Centre Information. The producer needs to register all the details of recycling firms like location, contact number etc with that the authorized Area Dealer Waste Collector, Zone Dealer Waste Collector.

8. Admin Module: -To keep track the medical product that are not sold and Car maintenance record to control air pollution- for Green computing. If the medical or any other products are not get sold in the market till expiry date then in such cases the notification/ alert message generated to the retailer along with the government authorized person, if registered with this system. The review of same product taken after 15 days to ensure that same medical product is not kept for sale in the market. Also, in other cases like the car maintenance records the notification given after regular interval of time which is help to support the movement of green computing. According to government rule the public vehicle run for 15 years, such rules can be monitor by the proposed system.

\subsubsection{Output Modules}

1. Response to User Validation Module: -Validate the user based on the credential enter by the user with the credential enter at the time of registration.

2. Response to Update Product Status request Success/ Failure Notification: -The ROLE enters at the time of registration decide the accessibility of the user. The ROLE played by "distributor-wholesaler (dealer)retailer" are not able to make "New Product" entry or they cannot update the status of the product that is not get enter by any of the registered producer. In such cases "Failure Notification" has been generated. If the update product status process is as per the rule and regulation then the "Success Notification" has been generated. For the "Check Product Status" request, if product is successfully searched then the product details send to the requested user.

3. Response to Product Status as "SOLD" (Store Warranty, Expiry date etc and Pre defined Commission/ charges are deposited in bank): - the customer charges along with the pre-define commission charges of producer, distributor and retailer are deposited in the bank.

4. Response to the Product Status as "Returned" (Release the deposit of customer, Distributor and retailer): -As the waste product returned by the customer, the deposit value is credited back to them and predefined parts of commission of distributor-retailer which get deposited in the bank are credited back to them.

5. Response to the Product Status as "Recycle Firm", Pre defined bonus point credited to the waste area /zone collector: -Through the chain product reach the market from producer to retailer, in the same way, the waste need to reach recycle firm from retailer but in reverse direction with the help of Area / Zone Dealer Waste Collector. As the recycle firm updates the database when waste reaches the recycle firm the bonus point is credited.

6. Response to the Product Status as "Recycled" Pre defined bonus point credited to the Recycle Firm: -As the recycle firm may takes week or month to finally recycle the product and also need to handle the sensitive returned products like Sonography machines, expire permit public vehicle like auto, taxi etc that can be re-used and leads to violating the Laws of regulating bodies. Hence as per the government or other bodies requirement, the recycle firm needs to make the video or other proof to completely demolish the waste product. The updating the database with the proof like video recording activity leads to win the bonus point in the account of recycle firm.

7. Response to the Admin Module: -If the "Status of the product as Medical-Expired" indicate the notification get send to producer, retailer and government authority that the expire medicine are in the market. If the "Status of the product as Medical-Expired Fifteen Days Overhead" indicate that the expire product are in the market with the same retailer, in such cases heavy taxation- punishment are put on that retailer and the case hand over to respective authority to cancel the Retailer Permit.

8. Send Service Centre information:-Base on the request generated for the enquiry, it sends the information of 
recycle Service Centre run by the authorized Area / Zone Dealer Waste Collector in the nearby location.

\section{VALIDATION OF PROPOSED MODEL}

The result generated by the proposed system can be compared and validated based on the following parameters:

Case study 1:- As per the survey of Indian express news paper [19] analyze that, taxpayers in Mumbai have spent over Rs 13,000 crore towards cleanliness over the past decade. The Brihanmumbai Municipal Corporation (BMC) had allocated Rs $8,839.5$ crore for solid waste management in the last five years, of which Rs 683.56 crore was used for development work and at least over Rs 5,000 crore for sewage disposal. Despite this, the city ranked 140th in the country on the Swachh Bharat survey of clean cities. The major allocation in the budget (2014-15) was to the solid waste management department (Rs 2,236.80 crore) followed by water and sewerage operations department (Rs 6,126.72 crore).

Validation 1 of proposed Model:- The proposed model kept the responsibility of waste recycles on the shoulder of the ROLE's (producer, distributor, retailer, customer, waste area/zone collector, recycle firm) hence the responsibility of government bodies' decreases which in turn save the budget amount.

Case Study 2:- As per the survey of Indian express and DNA news paper[20], of the 9,400 tones of municipal solid waste generated in Mumbai each day, the Deonar dumping ground (Mumbai), which has been staring at closure since 2011, receives 3,500 tones and Mulund dumping ground 2,200 tones. Neither of these dumping grounds currently in use has a waste processing unit, and mostly un-segregated and untreated garbage is simply dumped there, and the garbage catching fire due to the gases formed are common. The recently-opened Kanjurmarg dumping ground now processes 3,000 tons of waste. It is the city's only scientific landfill site, where the garbage is processed and methane gas is generated.

Validation 2 of proposed Model:- As the waste get recycled by the recycle firm the waste process by these dumping ground decreases gradually over a period of time.

\section{CONCLUSSION}

1. The implementation of proposed system helps to reduce the green house effect and various types of pollution. As per the survey [21], only $10 \%$ mobiles get recycled out of 50 million mobiles replaced by every year. (Note: 1 million mobiles recycled able to reduce the green house gas emission same as that of taking 1,368 cars taking off the road for a year).

2. The proposed system provides complete Product life cycle Information at One Place like all the registered manufactures, distributors, retailers, waste collector, recycle firm and "product status" information.

3. Mainly existing systems developed for e-waste management but different daily used products generate the other type of waste in large scale that needs to be monitor and recycled.

4. To recycle, to disassemble the e-waste requires the advanced and costly technology. Hence, the responsibility of recycling should be identifies at the time of product launch into the market, this can be done through the proposed system.
5. The sensitive returned recycle products can be reused and leads to violating the Laws of regulating bodies as per the record of past criminal cases in India. The proposed system can keep the record and track such products till final recycled video is updated. Sensitive Product: -Sonography machine, Revenue Stamp paper printing machines, Expire permit vehicle auto-taxi etc.

6. The proposed system help to identify an un-standardized products in the Indian market like LED bulb on which Indian government spend a lot of foreign exchanges currency without ensuring and getting the good quality service guaranty from China, due to lack of standardize marking system for an LED bulb in India.

7. The proposed system help to control the availability of chemicals into the open market like ACID. The Acid attack cases are happening in the society, due to lack of surveillance system on acid transaction in the market.

8. Excessive food storage, black marketing become the one of the reason of rising food price that can be monitor and control by the proposed system.

9. The proposed system able to identify the fake product or expired medical products through the option of "Status of Product". So that no one able to sell the expirer products or fake-dummy medical product.

10. The system supports the recycle market (Secondary Market) in more convincing ways which help to create more job opportunities and solve the unemployment problem in India.

\section{SCOPE OF FURTHER DEVELOPMENT}

1. Act as a evidence to Resolve Consumer Court Cases:

Earlier days handwritten bills are issued but now a day the machine bills are generated automatically in which the ink get disappear after few week (example ATM print slip). The bill can be act as a one of the evidence in the consumer court cases. As in case print vanishes then consumer can use the records of the system as evidences. [Note: - Product without warranty card are consider in above case where bill act as prime evidence.]

\section{To Increase the Government Revenue:}

As the purchase record of the product generated by the proposed system, if get approved by the government in various circumstances like tax deduction, government scheme etc then the trust on the system increases. As some of the retailer make fake (rough) bill or avoid giving the bill can be reduced in amount. As long as original selling records are get available with the proposed model which in turn increases the government revenue in exponential way.

3. To Register Customer Complaint Regarding Product: In some cases user register the complaint to the producer through given customer care number or email address. If producer ignore the valid suggestion then customer can record the complaint to the proposed system. (Note: The skin cream Fluocinolone Acetonide Cream IP (Flucort-H) used for medical purpose has not sealed from the bottom part as other tubes are concern. Due to that small pressing makes cream to flow from both the end which leads to the wastage of cream)

\section{ACKNOWLEDGMENTS}

I am extremely grateful and convey my heartfelt thanks to my internal guide, Professor Deepak Sharma of K. J. Somaiya college of Engineering, Vidyavihar Mumbai under the 
department of Computer Engineering for his valuable suggestions and encouragement throughout all the project development stages.

My vote of thanks to Mahatma Gandhi and saint Gaadge Maharaj, to organized "Clean-Up Mission" and make awareness about it which encourage me to work on this project.

My vote of thanks to the former president APJ Abdul Kalam sir to give us a "VISION 2020" [22] to make developed and powerful nation up to the year 2020 and the Prime minister of India, Mr. Narendra Modi to organized a "Swacha Bharat Abhiyan (Clean India)" campaign [23] This dream of visions encourages me to work on the social issues and search the possible solution on it.

My vote of thanks to Prof. B. M. Pradhan and Prof. Prasanna Shete, work under the Department of Computer Engineering, K. J. Somaiya College of Engineering Mumbai, for their valuable suggestions at the development stage- 1 of $\mathrm{ME}$ second year dissertation work.

My vote of thanks to Prof. Manish Pote work under the Department of Computer Engineering, K. J. Somaiya College of Engineering Mumbai, for their guidance on "How to Read a research Paper [24] in three passes, to extract valuable content".

Finally, I convey my vote of thanks to the IJCA editor and its team members for their valuable suggestions in the publication phase.

\section{REFERENCES}

[1] Greenpeace 2005, "Recycling of electronic wastes in china and India: workplace and environmental contamination",

http://www.greenpeace.org/raw/content/china/en /press/reports/recycling -of-electronic-wastes.pdf, published on Mar-2007.

[2] ToI (Times of India), "India to generate 1.5 lakh tone ewaste a year by 2020 - MAIT", online available: http://timesofindia.indiatimes.com/tech/technews/hardwa re/Inda-to- generate-1-5-lakhtonne-e-waste-a-year-by2020-MAIT.

[3] Siddharth Ghansela, "Green strategy for reducing ewaste", ISSN: 2277128X, International Journal of Advanced Research in Computer Sci. and Software Engg, Volume 3, June 2013.

[4] Yenming JJ Chen1 and Tien-Hua Wu1, "Effective ewaste management: the role of international cooperation and fragmentation”, MPRA Paper No. 25902, Oct 2010.

[5] Li Jian1, Zhang Shanshan and Tianjin, "Study e-waste management based on EPR system", ICEE.2010.213978-0-7695-3997-3/10, 2010 International Conference on E-Business and E-Government- China, IEEE DOI 10.1109 .

[6] Qian Yong, "OECD countries to expand producer responsibility policies on market structure and corporate behavior", Industrial Economic Research Journal, 2004.

[7] Zhao Yiping, WU Chun-you and Fu Ze-Qiang, "Based on circular economy EPR responsibility for Research and
Enlightenment of main options", Research and development Management-Journal, 2008.

[8] Ramzy Kahhat, Junbeum Kim and Ming Xu, "Proposal for an e-waste management system for United States", Conference: Electronics and Environment 2008, IEEE Xplore DOI: 10.1109 .

[9] Amanjot Singh and Deepak Bagai, "Electronic Waste Management - INDIAN PERSPECTIVE", ISBN: 97893-84209-03-2, SARC-IRF International Conference India, April-2014

[10] MoEF (Ministry of Environment and Forests), "Draft for E-waste (Management) Rules, 2011", online: http://moef.nic.in/ downloads/ rulesandregulations/1035e_eng.pdf, published on 2011

[11] CPCB, "schedule1 in e-waste management and handling rules",online :http://moef.nic.in/downloads/rules/schedlule1, 2011.

[12] Anil Kumar Saini and Abhishek Taneja, "Managing EWaste in India - A Review", ISSN 0973-4562, International Journal of Applied Engineering Research Vol.7 No.11, 2012

[13] S. Chatterjee and Krishna Kumar, "Effective e-waste management and recycling process involving formal, non-formal sectors", International Journal of Physical Sci. Vol.-4, 2009.

[14] Ethical engineering, "Extended producer responsibility", online available: http://ethicalengineering.org.

[15] Bandopahdyay A, "A Regulatory Approach for E-Waste Management in India" International Journal Environment and waste management, vol.2, Nos. 1/2, 2008.

[16] S.L. Adigun, "Humanitarian challenges and Opportunities", IEEE Global Humanitarian tech. conference, pp.6670, 2012.

[17] Mingzhong Ren and Sukun Zhang, "Concentrations and Profiles of Polychlorinated Dioxins and Furans in a Discarded E-Waste Open Burning Site", IEEE-ISSN 2151-7614, 2010.

[18] S. Devika, "Environmental Impact of Improper Disposal of Electronic Waste", IEEE, ISSN 978-1-42449184-1, 2010

[19] Greenpeace 2005, "Recycling of Electronic Wastes in China and India:", http://www.greenpeace.org/raw/content/china/en/ press/reports/recycling-of-electronic-wastes.pdf, Mar2007.

[20] A.P.J. Abdul Kalam and Y.S.Rajan, "INDIA 2020 vision for the new millennium", Publisher Penguin Books 2002.

[21] Narendra Modi, "Swachh Bharat Abhiyan", launched at Rajpath in New Delhi on $2^{\text {nd }}$ Oct 2014, onlinepmindia.gov.in/en/government_tr_rec/swachh-bharatabhiyan2/".

[22] S. Keshav, "How to read a research paper (in a three passes)", University of Waterloo Canada, keshav@uwaterloo.ca. 